\title{
Strategies to Increase Postpartum Contraception in Palu City
}

\author{
Ketut Suarayasa*(iD, Elli Yane, Miranti Miranti, Yuli Fitriana \\ Medical Studies Program, Faculty of Medicine, Tadulako University, Palu, Indonesia
}

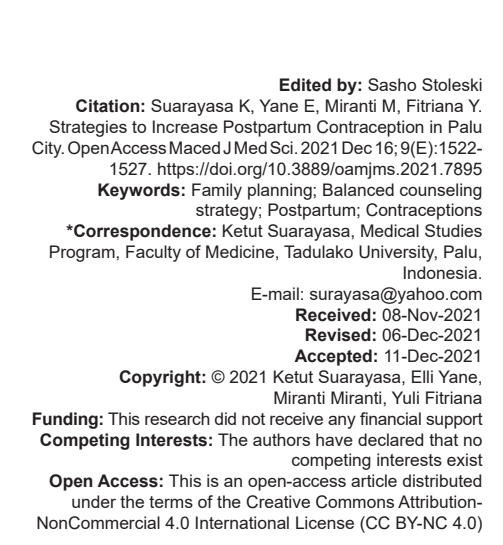

\section{Introduction}

Based on the Inter-Census Population Survey (in Indonesia: Survei Penduduk Antar Sensus, abbreviated: SUPAS) in 2015, the total population of Indonesia in 2020 is 269.6 million [1]. This large population can cause problems when the increase in fertility rates and population growth rate is not in line with the increase in population quality [2]. Demographically, fertility is defined as the result of reproduction as indicated by the number of live births. Fertility is one of the contributors to the high birth rate of mortality and migration [3]. One of the efforts that can be done to control the birth rate is through the family planning program (in Indonesia: Keluarga Berencana, abbreviated: $K B$ ), through the use of contraceptives by couples of childbearing age [2].

The National Population and Family Planning Agency of Indonesia (in Indonesia: Badan Kependudukan dan Keluarga Berencana Nasional, abbreviated: $B K K B N$ ) states that the long-term contraceptive method (in Indonesia: Metode Kontrasepsi Jangka Panjang, abbreviated: $M K J P$ ) is the most effective contraceptive method with a success rate exceeding 95\% [4]. However, the results of the Indonesian demographic and health survey in 2017 stated that only $13.2 \%$ of currently married women of reproductive age used long-term contraceptive methods, even though the mid-term target

\begin{abstract}
AROUND: Fertility is contributed to the high birth rate, mortality, and migration. One effort to control the birth rate is through the family planning program, using contraceptives by couples of childbearing age. The family planning reproductive health, and reduces maternal mortality. educational model on changes in postpartum contraception behavior in pregnant women

METHODS: The research used a quasi-experiment design with a non-randomized pre-test and post-test design, with
\end{abstract} LTS: The results showed that there was a significant improvement in knowledge $(p=0.00)$, attitude $(p=0.00)$ nd the use of postpartum contraceptives compared to the usual counseling method. of the National Medium-Term Development Plan (in Indonesia: Rencana Pembangunan Jangka Menengah Nasional, abbreviated: RPJMN) in 2016 had to reach $21.1 \%$ [5]. The purpose of the family planning program is to regulate the distance between mothers' pregnancies, prevent early or late age pregnancies, quality reproductive health, and reduce maternal mortality [6].

A study in the Congo showed that the barriers to using postpartum contraception were lack of knowledge, fear of side effects, religious considerations, and husband's support [7]. Educational factors, income, parity, and previous counseling history are also related to postpartum contraception participation [8]. Studies conducted in nine regions in Indonesia show that giving pregnant women a balanced counseling strategy can increase the percentage of postpartum family planning, where postpartum mothers use contraception before they return from service facilities [9]. Another study also showed that respondents who received a balanced counseling strategy were 4.2 times more likely to use postpartum contraception [10]. A recent study showed that $80 \%$ of pregnant women in the third trimester received a balanced family planning counseling strategy used contraception immediately after delivery. In addition, the choice of postpartum contraception is influenced by maternal age over 20 years, parity of more than two children, sufficient knowledge, and husband's support [11]. 
Based on the Central Sulawesi health profile data in 2018, the percentage of postpartum contraception coverage for the Central Sulawesi is $45 \%$ [12]. Meanwhile, according to the mother and child health $(\mathrm{MCH})$ section report of the Palu City Health Office, the coverage of postpartum contraception for Palu city in 2020 is $47.7 \%$ (Palu City Health Office, 2020). This figure is not much different from the previous postpartum contraception coverage. The stagnation of data on family planning services is due to the lack of optimal counseling to communicate information and education for family planning services. In addition, internal factors from the community also affect the stagnation of family planning services, including age, parity, age of the youngest child, spouse, cost, belief and culture, education level, level of knowledge, and status of women [13].

Data from the $\mathrm{MCH}$ section of the Palu City Health Office also show that there are several Public Health Center in Palu city with low postpartum contraception coverage $(<10 \%)$, including Mamboro Health Center $(0.0 \%)$, Mabelopura Health Center (1.6\%), Public Health Center Nosarara (4.0\%), Bulili Health Center (9.3\%), and Birobuli Health Center $(9.5 \%)$. The results of the initial interview with one of the leaders of the Public Health Center stated that the low coverage of postpartum contraception was due to the lack of education of midwives during antenatal care, low awareness of maternity mothers, lack of husband/family support, and the absence of an appropriate strategy to increase maternal awareness of using contraception, immediately after giving birth.

Based on the description above, this study aims to assess the effectiveness of the educational model of the balanced family planning counseling strategy (BFP-CS) on changes in postpartum contraception behavior in pregnant women.

\section{Methods}

This research used a quasi-experimental design with a non-randomized pre-test and post-test with a control group design. The first measurement (pre-test) was carried out on the intervention group and the control group. After, an intervention was carried out in education on a BFP-CS to pregnant women and their families (husbands), while the control group was not given any treatment. The research was located in Palu city, Talise Public Health Center (Intervention Group) and Singgani Public Health Center (Control Group). The population in this study was all third-trimester pregnant women who visited the research location with a sampling technique using purposive sampling, totaling 43 respondents for each group. The study's independent variable was the education module/guideline for the BFP-CS, and the dependent variable was the knowledge, intention, and action of using postpartum contraceptives. Data analysis was in univariate analysis to describe the knowledge, intentions, and actions of using postpartum contraception in the intervention and control groups. Bivariate analysis was to determine the differences between the pre-test and post-test of each group using the Wilcoxon and Chi-square tests and the differences between groups using the Mann-Whitney test.

Figure 1 shows the diagrams and cards for counseling and helps with the family planning counseling process, while Figure 2 shows a guidebook that was prepared to make it easier for midwives to understand the stages of family planning counseling.

\section{Results}

\section{Characteristics of respondents}

Table 1 shows that the most of the pregnant women in the intervention and control groups who were respondents aged $20-35$ years, about 68 people $(79 \%)$, the number of children two was 70 people (81\%), estimated gestational age 38-42 weeks was 41 people $(48 \%)$ and had never used contraception before was 59 people (69\%).

Table 1: Characteristics of respondents in the intervention group and control group

\begin{tabular}{lll}
\hline Variable & N & $(\%)$ \\
\hline Age & 6 & \\
$<20$ & 68 & 7 \\
$20-35$ & 12 & 19 \\
$>35$ & & \\
Number of children & 70 & 81 \\
$\quad \leq 2$ & 16 & 19 \\
$>2$ & & \\
Estimated gestational age & 20 & 23 \\
$28-32$ weeks & 25 & 29 \\
$33-37$ weeks & 41 & 48 \\
$38-42$ weeks & 27 & 31 \\
Previous contraceptive use & 59 & 69 \\
$\quad$ Yes & & \\
No & &
\end{tabular}

\section{Univariate analysis}

Table 2 shows a significant improvement from pre-test to post-test on the knowledge (from $44 \%$ of good

Table 2: Knowledge, attitudes, intentions, and use of contraceptive devices before and after education through providing explanation of balanced family planning counseling strategies in intervention groups at talise health centers in 2021

\begin{tabular}{|c|c|c|c|c|}
\hline \multirow{2}{*}{$\begin{array}{l}\text { Intervention groups } \\
\text { Variable }\end{array}$} & \multicolumn{2}{|c|}{ Pre-test } & \multicolumn{2}{|c|}{ Post-test } \\
\hline & $\mathrm{n}$ & $(\%)$ & $\mathrm{N}$ & $(\%)$ \\
\hline \multicolumn{5}{|c|}{ Knowledge of the use of contraceptives } \\
\hline Good & 19 & 44 & 40 & 93 \\
\hline Less & 24 & 56 & 3 & 7 \\
\hline \multicolumn{5}{|c|}{ Attitudes in the use of contraceptives } \\
\hline Good & 12 & 28 & 40 & 93 \\
\hline Less & 31 & 72 & 3 & 7 \\
\hline \multicolumn{5}{|c|}{ Intentions in the use of contraceptives } \\
\hline Good & 17 & 40 & 38 & 88 \\
\hline Less & 26 & 60 & 5 & 12 \\
\hline \multicolumn{5}{|c|}{ Action in the use of contraceptives } \\
\hline Good & 0 & 0 & 38 & 88 \\
\hline Less & 0 & 0 & 5 & 12 \\
\hline
\end{tabular}


knowledge to $93 \%$ of good knowledge), attitude (from $28 \%$ of good to $93 \%$ of good), and intention (from $40 \%$ of good to $88 \%$ of good). While on the action variable, there were 38 mothers (88\%) who used one of the contraceptives.

Table 3 shows a significant improvement from pre-test to post-test on knowledge (from $58 \%$ of good knowledge to $77 \%$ of good knowledge), attitude (from $37 \%$ of good to $63 \%$ of good), and intention (from $40 \%$ of good to $74 \%$ of good). While on the action variable, 17 mothers $(40 \%)$ decided to use one of the contraceptives.

Table 3: Knowledge, attitudes, intentions, and use of contraceptive devices before and after education through providing explanation of balanced family planning counseling strategies in control groups at talise health centers in 2021

\begin{tabular}{|c|c|c|c|c|}
\hline \multirow{2}{*}{$\begin{array}{l}\text { Control groups } \\
\text { Variable }\end{array}$} & \multicolumn{2}{|c|}{ Pre test } & \multicolumn{2}{|c|}{ Post test } \\
\hline & $\mathrm{N}$ & $(\%)$ & $\mathrm{N}$ & $(\%)$ \\
\hline \multicolumn{5}{|c|}{ Knowledge of the use of contraceptives } \\
\hline Good & 25 & 58 & 33 & 77 \\
\hline Less & 18 & 42 & 10 & 23 \\
\hline \multicolumn{5}{|c|}{ Attitudes in the use of contraceptives } \\
\hline Good & 16 & 37 & 27 & 63 \\
\hline Less & 18 & 42 & 10 & 23 \\
\hline \multicolumn{5}{|c|}{ Intentions in the use of contraceptives } \\
\hline Good & 17 & 40 & 32 & 74 \\
\hline Less & 26 & 61 & 11 & 26 \\
\hline \multicolumn{5}{|c|}{ Action in the use of contraceptives } \\
\hline Good & 0 & 0 & 17 & 40 \\
\hline Less & 0 & 0 & 26 & 60 \\
\hline
\end{tabular}

\section{Bivariate analysis}

Table 4 shows significant differences in the variables of knowledge, attitude, intention, and use of contraceptives before and after the intervention $(p<0.05)$. This shows that the BFP-CS significantly changed the research variables.

Table 4: Differences in knowledge and attitudes about family planning before and after treatment in the intervention group

\begin{tabular}{|c|c|c|c|c|c|}
\hline \multirow[t]{2}{*}{ Variable } & \multirow[t]{2}{*}{ Pre-test } & \multicolumn{2}{|c|}{ Post-test (\%) } & \multirow[t]{2}{*}{ Total (\%) } & \multirow[t]{2}{*}{$\mathrm{p}$} \\
\hline & & Good & Less & & \\
\hline \multirow{3}{*}{$\begin{array}{l}\text { Knowledge of the use of } \\
\text { contraceptives }\end{array}$} & Good & $16(84)$ & $3(16)$ & $19(100)$ & \multirow[t]{3}{*}{$0.000^{*}$} \\
\hline & Less & $24(100)$ & $0(0)$ & $24(100)$ & \\
\hline & Total & $40(93)$ & $3(7)$ & $43(100)$ & \\
\hline \multirow{3}{*}{$\begin{array}{l}\text { Attitudes in the use of } \\
\text { contraceptives }\end{array}$} & Good & $11(92)$ & $1(8)$ & $12(100)$ & \multirow[t]{3}{*}{$0.000^{*}$} \\
\hline & Less & $29(94)$ & $2(6)$ & $31(100)$ & \\
\hline & Total & $40(93)$ & $3(7)$ & $43(100)$ & \\
\hline \multirow{3}{*}{$\begin{array}{l}\text { Intentions in the use of } \\
\text { contraceptives }\end{array}$} & Good & $16(94)$ & $1(6)$ & $17(100)$ & \multirow[t]{3}{*}{$0.000^{*}$} \\
\hline & Less & $22(85)$ & 4 (15) & $26(100)$ & \\
\hline & Total & $38(88)$ & $5(12)$ & $43(100)$ & \\
\hline \multirow{3}{*}{$\begin{array}{l}\text { Action in the use of } \\
\text { contraceptives }\end{array}$} & Good & $38(88)$ & $5(12)$ & $43(100)$ & \multirow[t]{3}{*}{$0.000^{* *}$} \\
\hline & Less & 0 & 0 & 0 & \\
\hline & Total & $38(88)$ & $5(12)$ & $43(100)$ & \\
\hline
\end{tabular}

Table 5 shows the differences in the knowledge and attitude variables $(p<0.05)$, although the differences

Table 5: Differences in knowledge and attitudes about family planning before and after treatment in the control group

\begin{tabular}{|c|c|c|c|c|c|}
\hline \multirow[t]{2}{*}{ Variable } & \multirow[t]{2}{*}{ Pre-test } & \multicolumn{2}{|c|}{ Post-test (\%) } & \multirow[t]{2}{*}{ Total (\%) } & \multirow[t]{2}{*}{$\mathrm{p}$} \\
\hline & & Good & Less & & \\
\hline \multirow{3}{*}{$\begin{array}{l}\text { Knowledge of the use of } \\
\text { contraceptives }\end{array}$} & Good & $22(88)$ & $3(12)$ & $25(100)$ & \multirow[t]{3}{*}{$0.033^{*}$} \\
\hline & Less & $11(61)$ & 7 (39) & $18(100)$ & \\
\hline & Total & $33(77)$ & $10(23)$ & $43(100)$ & \\
\hline \multirow{3}{*}{$\begin{array}{l}\text { Attitudes in the use of } \\
\text { contraceptives }\end{array}$} & Good & $8(50)$ & $8(50)$ & $16(100)$ & \multirow[t]{3}{*}{$0.034^{*}$} \\
\hline & Less & $19(70)$ & $8(30)$ & $27(100)$ & \\
\hline & Total & $27(63)$ & $16(37)$ & $43(100)$ & \\
\hline \multirow{3}{*}{$\begin{array}{l}\text { Intentions in the use of } \\
\text { contraceptives }\end{array}$} & Good & $15(88)$ & $2(12)$ & $17(100)$ & \multirow[t]{3}{*}{$0.157^{*}$} \\
\hline & Less & $6(23)$ & $20(77)$ & $26(100)$ & \\
\hline & Total & $21(49)$ & $22(51)$ & $43(100)$ & \\
\hline \multirow{3}{*}{$\begin{array}{l}\text { Action in the use of } \\
\text { contraceptives }\end{array}$} & Good & $17(40)$ & $26(60)$ & $43(100)$ & \multirow[t]{3}{*}{$0.170^{* *}$} \\
\hline & Less & 0 & 0 & 0 & \\
\hline & Total & $17(40)$ & $26(60)$ & $43(100)$ & \\
\hline
\end{tabular}

were not significant. However, there was no difference in the variables of the mother's intentions and actions in using postpartum contraception between before and after being counseling ( $p>0.05)$.

Table 6 in the intervention and control groups shows the difference between the pre-test and post-test results (this indicated that both approaches had positive results). However, there were significant differences in the research variables $(p<0.05)$. This shows that the BFP-CS intervention was quite effective in increasing knowledge, attitudes, intentions, and use of postpartum contraception compared to the counseling model used so far (using flipcharts and posters).

Table 6: Comparison of mothers' knowledge levels and attitudes about family planning in the intervention group and control group

\begin{tabular}{|c|c|c|c|c|c|}
\hline \multirow[t]{2}{*}{$\begin{array}{l}\text { Variable } \\
\text { nat }\end{array}$} & \multirow[t]{2}{*}{ Control } & \multicolumn{2}{|c|}{ Intervention (\%) } & \multirow[t]{2}{*}{ Total (\%) } & \multirow[t]{2}{*}{$\mathrm{p}^{\star \star \star \star}$} \\
\hline & & Good & Less & & \\
\hline \multirow[t]{3}{*}{ Knowledge } & Good & $32(97)$ & $1(3)$ & $33(100)$ & \multirow[t]{3}{*}{0.036} \\
\hline & Less & $8(80)$ & $2(20)$ & $10(100)$ & \\
\hline & Total & $40(93)$ & $3(7)$ & $43(100)$ & \\
\hline \multirow[t]{3}{*}{ Attitudes } & Good & $27(100)$ & $0(0)$ & $27(100)$ & \multirow[t]{3}{*}{0.001} \\
\hline & Less & $13(81)$ & $3(19)$ & $16(100)$ & \\
\hline & Total & $40(93)$ & $3(7)$ & $43(100)$ & \\
\hline \multirow[t]{3}{*}{ Intentions } & Good & $16(76)$ & $5(24)$ & $21(100)$ & \multirow[t]{3}{*}{0.000} \\
\hline & Less & $22(100)$ & $0(0)$ & $22(100)$ & \\
\hline & Total & $38(88)$ & $5(12)$ & $43(100)$ & \\
\hline \multirow[t]{3}{*}{ Action } & Good & $13(77)$ & $4(23)$ & $17(100)$ & \multirow[t]{3}{*}{0.000} \\
\hline & Less & $25(96)$ & $1(4)$ & $26(100)$ & \\
\hline & Total & $38(88)$ & $6(12)$ & $43(100)$ & \\
\hline
\end{tabular}

\section{Discussion}

Knowledge, attitudes, intentions, and use of contraceptive devices before and after education through providing explanation of balanced family planning counseling strategies in intervention and control groups

There were differences in the pre-test and posttest results on the four research variables (knowledge, attitudes, intentions, and use of contraceptives), both in the intervention and control groups. According to the theory proposed by Notoatmodjo (2010) in [12], effective family planning counseling can increase knowledge of family planning which will form certain beliefs so that a person behaves according to his beliefs.

Research conducted by Hasyati Al et al. (2019) [14] also showed that mothers with less or sufficient knowledge after being given a BFP-CS used postpartum contraception higher than mothers who were not given a BFP-CS. However, mothers who were not given the BFP-CS (control group) also showed increased knowledge, attitudes, and actions in using postpartum contraceptives, although the results were not as significant as in the intervention group.

Another study by Ake et al. (2020) [15] showed that in the intervention group, there was a significant difference in knowledge before and after being BFP-CS 


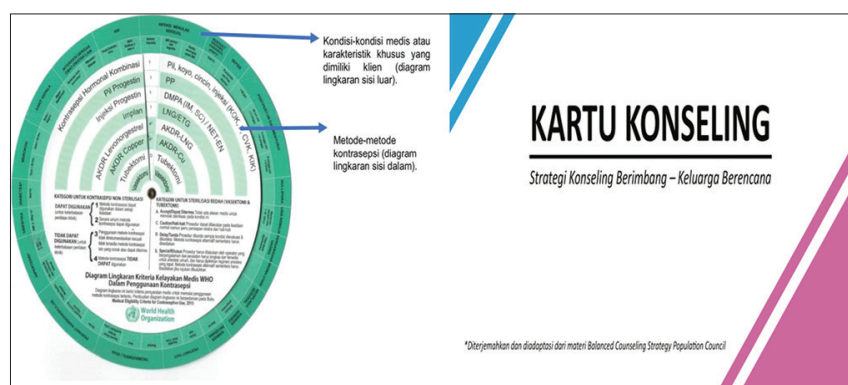

Figure 1: Diagram of assistance and counseling card of strategi konseling berimbang keluarga berencana

with video learning in the third trimester pregnant women at the Pitumpanua Public Health, Wajo Regency $(p<0.05)$. This increase in knowledge (post-delivery intrauterine device) was seen more quickly in the intervention group given BFP-CS with video learning.

\section{Differences in knowledge, attitudes,} intentions, and use of contraceptive devices before and after education on BFP-CS in the intervention and control groups

Analysis using the Wilcoxon test showed significant differences in the variables of knowledge, attitude, intention and use of contraceptives before and after the BFP-CS intervention $(p<0.05)$. Then, in the control group, there was no significant difference between knowledge, attitude and use of contraceptives. At the same time, the intention variable was not found any difference. Knowledge is the result of knowing, and this occurs after people have sensed a certain object. Sensing of objects occurs through the five human senses, namely, sight, hearing, smell, taste, and touch. Knowledge or cognition is critical in creating an action (over behavior) [16].

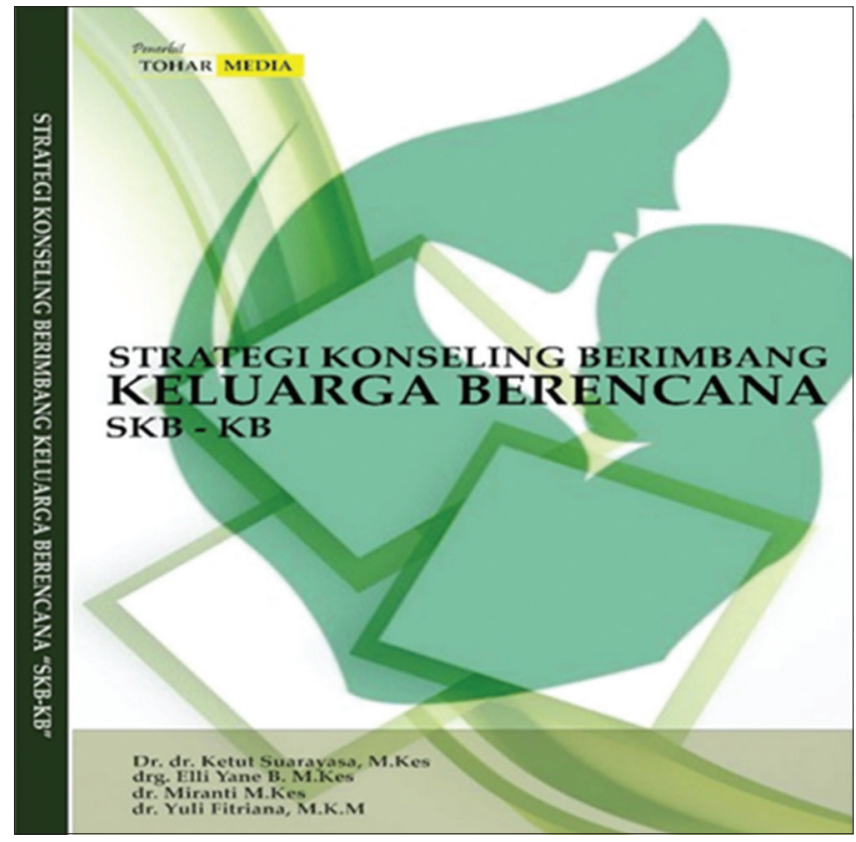

Figure 2: Strategi konseling berimbang keluarga berencana module
Improving knowledge and attitudes require appropriate interventions. Family planning counseling in its implementation is not optimal. Meanwhile, counseling carried out in a structured and balanced manner can increase knowledge, attitudes, and use of contraception [17].

The family planning balanced counseling strategy is a client-decision-oriented family planning counseling method where the rights of the counselor and client are equal, and decisions are not influenced by the counsellor's wishes [18]. This is in accordance with a study conducted in Ethiopia on couples of childbearing age which stated that counseling could help women increase knowledge and avoid misunderstandings about each contraceptive option [19]

\section{Effectiveness of education through balanced family planning counseling strategies on changes in postpartum contraception behavior}

Using the Mann-Whitney test, comparative analysis between the intervention and control groups showed a significant difference in all study variables $(p<0.05)$. Knowledge is the result of knowing, and this occurs after people have sensed a particular object. Meanwhile, attitude is the level of a person to have a good or bad evaluation of certain behaviors. A person's attitude is determined by a person's belief in the behavior to be displayed. If the individual has a perception that using contraception is a positive behavior, then the individual will have a positive attitude toward the acceptance of contraceptives. A person's positive attitude must be accompanied by strong beliefs to perform positive behavior, such as using postpartum contraception.

Attitude is a reaction or response that is still closed from a person to a stimulus or object. Attitudes clearly indicate the suitability of reactions to certain stimuli [20]. The response will only arise when the individual is faced with a stimulus that requires an individual reaction. Evaluation response means that the reaction expressed as an attitude arises based on the evaluation process within the individual in the form of positive and negative values that can be a reaction to the attitude object [21].

The intention is a person's desire to act with the stimulus he gets [16]. The intention in this study was stimulated by the provision of family planning counseling in the hope that pregnant women after counseling would intend to use modern contraception. According to the [22] in Theory Reason Action, subjective attitudes and norms determine behavior based on intentions. The more positive attitudes and subjective norms a person has, the more positive the intention will be.

This study showed that the provision of counseling during antenatal care could increase the frequency of maternal intentions regarding postpartum 
contraception. There was a difference in intention in the intervention group $(p<0.05)$ and the control group $(p>0.05)$. The final result is seen in the action variable. Postpartum contraceptives were very good in the intervention group (88\% decided to use one of the postpartum contraceptives) compared to the control group $(42 \%$ decided to use one of the postpartum contraceptives).

This is in line with research conducted by [23] which showed a significant relationship with intention to use postpartum contraception, where women who had received counseling intervention during antenatal care were 1.7 times more likely to use contraception. The study conducted by [24] showed the results of $\mathrm{RR}, 1.11 ; 95 \% \mathrm{Cl}, 1.01-1.22$, which means that there is an intention from the client to use more effective contraception in the future where the provision of adequate family planning counseling tends to increase the use of contraception after childbirth.

\section{Conclusion}

Based on the study results, there was an increase in the percentage of knowledge, attitude, intention, and use of postpartum contraceptives in the intervention group and control group and differences in knowledge, attitudes, intentions, and use of contraceptives in the intervention group $(p<0.05)$. In the control group, only the intention variable was not significant. The family planning balanced counseling strategy was very effective in increasing knowledge, attitudes, intentions, and postpartum contraception compared to the usual counseling method $(p<0.05)$.

\section{Acknowledgments}

The author thanks to all who contributed to this research, the head of the public health center, midwives, other medical personnel, and the respondents who participated in the research.

\section{References}

1. Kusnandar VB. Inilah Proyeksi Jumlah Penduduk Indonesia 2020, Databoks; 2020.

2. Syahidah SA, Budyanra B. Determinan Status Penggunaan Metode Kontrasepsi Jangka Panjang Di Indonesia Tahun 2017, Seminar Nasional Official Statistics; 2021. https://doi. org/10.34123/semnasoffstat.v2020i1.403
3. Jatmiko YA, Wahyuni S. Determinan Fertilitas Di Indonesia Hasil Sdki 2017, Euclid; 2019. https://doi.org/10.33603/e.v6i1.1516

4. BKKBN, Badan Pusat Statistik, Kementerian Kesehatan, and IFC International, Survei Demografi dan Kesehatan Indonesia 2017; 2017.

5. SDKI, Laporan Pendahuluan Survey Demografi dan Kesehatan Indonesia 2017, in Survey Demografi dan Kesehatan Indonesia 2017; 2017.

6. Gonçalves MJ, Suariyani NL, Suryadhi NT. Relationship of knowledge and attitude with use of contraceptive devices in efa at comoro health center dili timor leste. Public Health Prev Med Arch. 2014;2(1):1-9. https://doi.org/10.15562/phpma.v2i1.121

7. Mathe JK, Kasonia KK, Maliro AK. Barriers to adoption of family planning among women in Eastern Democratic Republic of Congo. Afr J Reprod Health. 2011;15(1):69-77.

8. Abbas M, Abbas M, Hadijono S, Emilia O, Hartono E. The effect of counseling during childbirth on postpartum family planning participation in kolaka district. J Kesehatan Reprod. 2017;4(2):1-8.

9. Lambe FM, Riswan I, Blanchard H. Providing family planning post partum counseling using balance counseling strategy approach in 9 districts in Indonesia. Int J Qual Health Care. 2017;9(1):40-1.

10. Ahyani R. The Relationship between a Balanced Counseling Strategy for Postpartum Mothers and the Use of Post-partum Contraception at RSU PKU Muhammadiyah Delanggu Klaten. Journal Universitas Gadjah Mada; 2018.

11. Hasyati H, Masni M, Salmah AU, Tamar M. The influence of balanced counseling strategy on mother toward use of post partum family planning. Enferm Clin. 2020;30 Suppl 4:431-5. https://doi.org/10.1016/j.enfcli.2019.10.116

12. Dinas Kesehatan Provinsi Sulawesi Tengah, Profil Kesehatan Provinsi Sulawesi Tengah Tahun 2018, Profil Kesehatan Provinsi Sulawesi Tengah Tahun 2018; 2018.

13. Haris VS. Family planning counseling using flashcards to increase knowledge, attitude and participation in postpartum IUD and MOW contraceptives. J Kesehatan. 2017;8(2):296. https://doi.org/10.26630/jk.v8i2.497

14. Hasyati Al, Masni M, Tamar M, Stang Al. The influence of balanced counseling strategy on mother towards participants of post partum family planning at puskesmas kassi-kassi makassar. EAS J Nurs Midwifery. 2019;0966(4):119-25.

15. Ake I, Ramadany S, Pelupessy N, Ahmar H. Jurnal Keperawatan Muhammadiyah Peningkatan Pengetahuan Ibu Tentang IUD Pasca Persalinan Dengan Intervensi Strate-gi Konseling Berimbang (SKB) Dengan Video Learning; 2020. p. 30-4.

16. Notoatmodjo S. IImu Perilaku Kesehatan. Jakarta: PT Rineka Cipta; 2014.

17. Egarter C, Grimm C, Nouri K, Ahrendt HJ, Bitzer J, Cermak C Contraceptive counselling and factors affecting women's contraceptive choices: Results of the CHOICE study in Austria. Reprod Biomed Online. 2012;24(7):692-7. https://doi. org/10.1016/j.rbmo.2011.12.003

18. Kemenkes, BKKBN, JHCCP, Jhpiego. Modul Pelatihan Nakes: Strategi Konseling Berimbang Keluarga Berencana (SKB KB) untuk Dokter, Bidan dan Perawat, Jakarta; 2018.

19. Gebremariam A, Addissie A. Knowledge and perception on long acting and permanent contraceptive methods in Adigrat town, Tigray, Northern Ethiopia: A qualitative study. Int J Family Med. 2014;2014:878639. https://doi.org/10.1155/2014/878639 PMid:25140252

20. Notoatmodjo S. Promosi Kesehatan dan IImu Perilaku. Jakarta: PT Rineka Cipta; 2007.

21. Azwar S. Sikap Manusia Teori dan Pengukurannya. Yogyakarta: Pustaka Pelajar; 2011

22. Ajzen I. Attutudes, Personality and Behavior. $2^{\text {nd }}$ ed. Berkshire 
UK: Open University Press Mc Graw Hill Education; 2005.

23. Keogh SC, Urassa M, Kumogola $Y$, Kalongoji $S$, Kimaro $D$, Zaba B. Postpartum contraception in northern tanzania: Patterns of use, relationship to antenatal intentions, and impact of antenatal counseling. Stud Fam Plann. 2015;46(4):405-22. https://doi.org/10.1111/j.1728-4465.2015.00040.x

\section{PMid:26643490}

24. Wuni C, Turpin CA, Dassah ET. Determinants of contraceptive use and future contraceptive intentions of women attending child welfare clinics in urban Ghana. BMC Public Health. 2017;18(1):78. https://doi.org/10.1186/s12889-017-4641-9 PMid:28764670 